Historic, Archive Document

Do not assume content reflects current scientific knowledge, policies, or practices. 


(he some forty bnshels. Undoubtedly the tree on the Georgia off. by some South Carolima relative of the owner. The South Carolina specimen

LIBERTY COUNTY CONTRIBUTRS TWO GRTAT PEARS TO AMERICAN HORTICULTURT, FACH OF ACCIDENTAL LOCAI. ORIGIN AND WONDERFUI VAIUE.

(By George D. Iowe, in The Savannah Moxning News, Aug. 20, 1922.)

BAXLEY, Ga., Aug. 19.- Some time in the winter of 1851, Maj. Jack LaConte bought from a nurseryman in Philadelphia a single speeimen of an imported Chinese sand pear which he brought to his farm in Liberty County, Georgia.

Three products of that farm attained world-wide fame, Professors John and loseph LeConte, founders of the University of California, the foremost phy sicist and the leading geologist of their time, and the "Leconte" pear. After coming into bearing this pear attracted great attention and thousands of trees propagated from it were set all over South Georgia.

For some years the pear industry of the coastal country and Sonthwest Geor gia was much more important and even more promising than the new peach activity farther up state. However, a destructive blight, that was beyond the skill of horticulturists to figlt effectively, attacked the orchards and they soon passed out of existence, but not before they had absolutely proven that South Georgia from the standpoint of soil and limate is admirably adapted to pear growing.

\section{A Curious Coincidence}

Fate plays strange tricks with sections as well as with individuals. Joseph LeConte, the Liberty County boy, around whose home no rock larger than a soft field pebble can be found, beeame professor of geology in the University of California, the leading mineral state, and a famus authority on min eralogy. John LeConte was hardly less famous as a physicist and in the domain of general science. The pear which could not be kept in South Georgia be cause of blight became California's most profitable horticultural aetivity. Californians say that for every net dollar the orange has brought into their state the pear has brought three. The pear orchards of the San Joaquin valley are more valuable acre for acre than the orange groves farther south. But for blight this development would have come about in South Georgia, much nearer the centers of population and where the American industry really began. But for the poverty of the State after the war and the lack of funds to support its institutions of higher learning, the brothers LeConte, might have been kept in their native state. South Georgia feels that she has done a great part by California.

Now Comos the Pineapple Pear

In the winter of 1888 Dr. C. C. Dan iel, a prominent Liberty County physician, drove up to the gate of the John D. Deloach plantation some forty miles south of the LeConte place and now in Long county. He handed Mr. DeLoael a pear switch with the remark that he had cut it from the finest pear tree he had ever seen in his life down on the island, advising $\mathrm{Mr}$. DeLoach to set it immediately, which he did. It was placed in a small orehard of blighting LeContes and Keiffers and grew off rapidly as the pear always does in Sonth Georgia. It came into bearing the sixth year from the switch and showed qnality and prodnetivity be rond expectation.
Before the performance of the tree was dead, and no one now living knows xactly where he got it. In those days Liberty county sportsmen hunted deer on all the islands, St. Catherines, Ossabaw, Blackbeard, Sapelo and St. Sitations lying in the desolation that folnegroes, and on any one of them the pear tree may have stood. On the is lands the pear does even better than on the mailand, aceording to old obervers of the early LeConte days.

Mrs. Lewis DeLoach Dasher inheritcome into bearing, produce bountiful erops yearly and remain unblighted among dying LeConte and Keiffer trees. After a few years she set out a few more trees and in later times propagated the pear in a small way, giving them to friends for the most part. The farm is isloated and no main-traveled road passes even nearby. Knowledge of the pear was confined to neighbors for blight sooner or later. Last year, its thirty-third from the switeh, the tree bore sixty-six bnshels of fruit, and an eight-ycar-old descendant yielded eighteen measured bushels. Thousands of bushels of these fine pears were fed to hogs duxing many years, but two years and has bought the erop since. Lately he also bought the farm which lies forty-two miles from Baxley and sev cnteen miles from the nearest shipping station over a deep, sandy road.

Proving the Blight Immunity

Ten years ago euttings were sent to the Georgia Experiment Station for comparison with blighting, varieties. When the young trees became established the horticulturists set to work to prove or disprove the claim to immnnitures of pear blight were inoculated into them; blighting wood from other varieties was grafted and budded into
them as they stood in a blighting block of LeContes and Keiffers. They came through unscathed. Horticulturists are chary about making unqualified statements, so the Georgia station does not say that the Pineapple pear is blightproof, but goes on record to the effect that they have not been able to bligint it cither naturally or artifieially, ancl that for orchard purposes on any seaje it may be rogarded as immune to blight. into the horticultural spotlight efforts were made to determine its exact origin. Much time lad elapsed and som inferences must be used in the process, but it appears evident that the origi nal Pineapple pear was given to a plaw. ter in South Carolina by a relative who was an officer in Commodore Perry' the middle fifties, and who brought th and in bearing, nine feet in eircumference just above the ground and with a tremendous spread of limbs. In its mon. On all of them were fine old planthere all her life. She saw this pear years and everybody expected it to ty from blight. Pure laboratory enlrooted pear from China when he returued. That tree now stands still vigorons stands alone in its generation outside of China,

\section{A Canning Pear Primarily}

The Pineapple pear, so-called because when ripe it has a distinet pineappleish odor, is essentially a canning proposi-
tion or for preserves, jams and marmalades. It is not regarded as an eating pear of high quality although snperior to the sand pears, as it lacks the gritty lumps shown by them and has a smooth. er flesh. It is medium in size as grown Mrs. Dasher, where no thinning is would average up well. Canners pronounce it better for their purpose than any other known to them, and they have lately visited the Dasher orchard from as far away as Indiana. Two small annual packs by a Waycross cannery have in the Pineapple pear.

Many Sonth Georgia farmers have driven over to the Dasher orchard lateral parties passing through Baxley last week. They know that their land is better adapted to pears than to any other fruit and that a greater tonnage of pears can be produced on an acre than of any other crop, agrienltural or horticultural, and only blight has kept out of pear growing up to now.

The pear prefers the lighter lands ly a South Georgia proposition, its preferred range lying between salt water and the Savannah-Americus-Montgomery line of the Seaboard. Above that line its early blooming habit may make bearing erratic, while Mrs. Dasher says that the old tree on her place has neving.

\section{Large Planting This Year}

It is reported that the available sup ply of nursery stock of the Pineapple
pear has all been secured for 1922 planting which will give an acreage of bout two thousand. The snpply i ikely to be ample after this year. Se ral authorities have said that within ten years the Pineapple pear industry ill bring more money into Georgia than the peach crop now yields and a few years thereafter will at least don-
ble it. It is to be noted that the new pear is so long-lived and so vigorous in growth that the ordinary $25 \times 25$
planting is too close. Horticulturists who have seen the Dasher orchard say $40 \times 40$ setting is as close as ean be sed safely. This is 27 to the acre.

A few pears of this variety on the St. Louis market early this season, hipper $\$ 1.80$ the bnshel. A cannery however, paid $70 \mathrm{e}$ for the run-of-oreh ard stock from wagons at the ear door and handled them in bulk like sweet potatoes. From a single group of small orchards around a little town that got in the game early, this canmery bought fifty carloads.

Pineapple pears, Lucretia dewberries and Okwola blueberries, all sandy land frnit crops newly introduced into South Georgia and all promising wonderful returns to the grower who gets into the game early, will soon make this section the center of a shipping and canning industry that will rival California in importanee. The whole territory lies near water transportation to the cen ters of population in the East, thous ands of miles nearer than the famons California fruit distriets. 
